J. Clin. Chem. Clin. Biochem.

Vol. 19, 1981, pp. 267-271

\title{
Interfacial Tension of Some Biological Fluids: A Comparative Study')
}

\author{
By $K$. Mottaghy and $A$. Hahn
}

\section{Abteilung Physiologie der Rheinisch-Westfälischen Technischen Hochschule Aachen}

(Received June 4/December 16,1980)

Summary: In describing physicochemical properties of interfacial interactions, the interfacial tension is a major parameter. In the case of biological or body fluids, the presence of surface active substances influence the value of the surface tension. Thus, several proposals have been made for methods to investigate the changes in surface tension. Alterations of surface tension (compared to those of the normal values, e.g. of amniotic fluid) may indicate a pathophysiological status.

This report presents data of systematically measured surface tensions of a few physiological fluids. Problems of methodology and data interpretation are discussed together with suggestions for new approaches, and comparisons are made with previously reported measurements.

\section{Grenzflächenspannung einiger biologischer Flüssigkeiten: Eine vergleichende Untersuchung}

Zusammenfassung: Die Grenzflächenspannung ist bei der Beschreibung physikochemischer Vorgänge an Grenzflächen eine wichtige Kenngröße.

Bei biologischen Flüssigkeiten, insbesondere bei Körperflüssigkeiten, wird der Wert der Grenzflächenspannung wesentlich von der Existenz grenzflächenaktiver Substanzen beeinflußt.

Um Änderungen der Grenzflächenspannung zu erfassen, sind bereits eine Reihe von Vorschlägen und Meßmethoden eingeführt worden. Es wurde beschrieben, daß die Veränderung der Grenzflächenspannung der Körperflüssigkeiten (z. B. Fruchtwasser) im Vergleich zu Normalwerten auf pathophysiologische Vorgänge hinweisen kann.

Der nachfolgende Bericht beschreibt systematische Untersuchungen an einigen physiologischen Flüssigkeiten. Es werden die Problematik der Dateninterpretation und der Meßmethodik - auch im Vergleich zu früheren Publikationen - zusammeṇ mit neuen Vorschlägen diskutiert.

\section{Introduction}

The interaction between biological fluids (e.g. blood, saliva, amniotic fluid, etc.) and non-biological surfaces artificial membranes, gas etc.) is a well-characterized field of investigation, especially for its clinical application. In general, surface contact interactions occur at the interface of gas/liquid, liquid/liquid and liquid/solid systems. Following examples demonstrate the importance of interfacial phenomena in biological systems: The blood (e.g. in open heart surgery) is in direct contact with gas in a bubble-oxygenator, or in contact with gas-permeable mëmbranes in a membrane-oxygenator $(1,2,3)$. Such contacts are also provided in dialysis and

\footnotetext{
1) Supported by "Ministerium für Forschung und Wissenschaft des Landes Nordrhein-Westfalen".
}

artificial heart and heart valves between blood and artificial surfaces (4). In all of these and other artificial organs, undesired interactions at interfaces limit seriously the duration of their application. In the case of the interaction between gases and biological liquids, the interfacial tension is one of the most important parameters which describe the phenomena occurring at the interface. One example is the direct measurement of surface tension of amniotic fluid in connection with the respiratory distress-syndrome $(5,6)$; measurements are also made with cerebrospinal fluids and other body fluids (see also tab. 4) (7-17).

Besides its clinical interest, the knowledge of the interfacial tension is required e.g. for liquid-liquid blood oxygenation (18) and could be helpful for blood filtering tests (19). 
The significance of the reports in the literature is difficult (when not impossible) to interpret, since different methods are used under different boundary conditions; the present report describes a systematic measurement of blood and a few other physiological fluids, where the importance of dynamic measurements - i.e. the change of surface tension with time, is emphasized. A new method is used. We propose the use of an inert liquid (we use fluorocarbons) as a reference fluid instead of air, against which the surface tension of the biological fluid is measured. The practical applications of these measurements are also discussed.

The high solubility for gases and the inertness of these liquids allows their application as gas carriers e.g. for synthetic blood, in organ perfusion, in liquid breathing, and in liquid-liquid-oxygenation as liquid membranes $(18,20,21)$.

\section{Surface and interfacial tension}

The existence of surface tension is best demonstrated by the tendency of water to form drops in the air. Different theoretical treatments and models were introduced for this phenomenon (for a discussion, see (22)). The surface tension which is manifested at the interface of two fluids (e.g. air/water) is measured in $\mathrm{mN} / \mathrm{m}(\mathrm{dyn} / \mathrm{cm})$; this actually does not have the dimensions of tension (pressure) which is given in $\mathrm{N} / \mathrm{m}^{2}\left(\mathrm{dyn} / \mathrm{cm}^{2}\right)$. Nevertheless, it has been shown by $L$. Prandtl (23) that the surface tension is in fact a tension.

In the case of two immiscible fluids such as water and oil, the term of interfacial tension is used instead of surface tension. If one or both liquids are surfaceactive, the interfacial value is a function of time (age of the fluids). This fact becomes very important for the case of biological fluids (see later discussion).

There are several methods for measuring interfacial tension (22); usual ones are: the ring-method, the dropweight method, the Wilhelmy-plate method, and the pendant drop method. We have used the well-known ring-method of Du Noüy (24). This method provides accurate correction factors, is easy to handle and has been used widely by other groups: A ring is immersed in phase I (see fig. 1). The surface of interfacial tension between phase I and phase II is determined by the force required to detach the metal ring from the surface. Phases I and II can form a liquid/gas or liquid/ liquid-system. The surface (interfacial) tension is given by the equation:

$$
\sigma=\frac{f}{4 \pi R}
$$

where $f$ is the measured force by a tensiometer and $R$ is the radius of the metal ring.

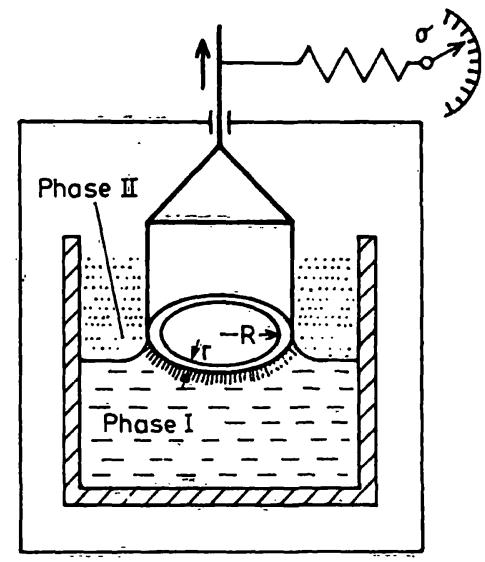

Fig. 1. Schematic diagram of the ring method.

For practical use, however, some corrections, depending on the physical properties of the system (25) are necessary. This is described in the next section.

\section{Materials and Methods}

\section{Equipment and procedure}

Tensiometer: A tensiometer Type $\mathrm{K} 8600$ was used (Firma Krüss, Hamburg). For this device, equation 1 can be modified into equation 2 , which includes a number of correction factors (25).

$$
\sigma=\left(\frac{\beta_{1} f}{4 \pi R}+C\right) \beta_{2}
$$

First, the instrument was calibrated according to equation 1 by weights between 0.5 to $1 \mathrm{~g}$. Here we obtain the ring-specific factor $\beta_{1}$ (the factor $\beta_{1}$ should not be evaluated by calibration of the device with water, since the smallest amounts of surface active agents influence a correct measurements). The factor $C$ for this device is equal to zero because the Kruss-tensiometer is linearly compensated to water at $20^{\circ} \mathrm{C}$ ( Fa. Krüss; technical information for the ring-method).

Finally, the main correction factor $\beta_{2}$ for the density of the fluids and the geometry of the ring was obtained from tables which are given in (26). Empirical equations are also presented in $(27,28)$ to approximate the correction factor $\beta_{2}$. The measure ments were carried out at $20^{\circ} \mathrm{C}$ and $37^{\circ} \mathrm{C}$. The measurement vessels were cleaned with chromosulfuric acid and were heated with gas flame before every new measurement.

\section{Chemicals and samples}

Liquids used are water (twice distilled), saline $(8.4 \mathrm{~g} / 1 \mathrm{NaCl})$, albumin (human plasma protein solution, Immuno $\mathrm{GmbH}$, FRG, Charge No. 308966 , containing per $100 \mathrm{ml}: 4.0 \mathrm{~g}$ protein (more than $95 \%$ albumin); $3.0 \mathrm{~g}$ glucose-monohydrate; $0.0665 \mathrm{~g}$ sodium capry late for stabilization), and FC-43 (3M-Company, Düsseldorf, FRG). FC-43 (perfluorotributylamine) is a biologically inert liquid (nonmiscible with blood and other biological fluids) with a density of $1.88 \mathrm{~kg} / \mathrm{h}$, boiling point $174^{\circ} \mathrm{C}$, low vapor pressure $\left(0.3\right.$ Torr at $25^{\circ} \mathrm{C}$ ), and a viscosity of $0.026 \mathrm{St}\left(=2.6 \cdot 10^{-6} \mathrm{~m}^{2} / \mathrm{s}\right)(18)$.

Blood was drawn by venipuncture from 8 male and female donors (anticoagulated by heparin, $7 \dot{5}$ units/ml) and used immediately. Blood with different haematocrit values was prepared by centrifugation of blood and subsequent removal or addition of plasma to adjust the desired haematocrit. Serum and plasma are also obtained from freshly drawn blood: Every measurement of the eight different samples was repeated five times. The amniotic fluid used was obtained in the 34th week of pregnancy and conserved by freezing. The volume of all liquids required for the measurements was $15 \mathrm{ml}$ 


\section{Results and Discussion}

In order to give some typical examples, table 1 summarizes the surface tension values for water (twice distillated), isotonic saline and our reference fluid FC-43 against air; besides the interfacial tension values of water and saline against $\mathrm{FC}-43$. Table 1 shows that $\mathrm{FC}-43$ possesses a lower value of surface tension; furthermore the interfacial tension values of water and saline are lower than their surface tension (The influence of the gas solubility upon surface tension and interfacial tension in the methods used here is negligible for the liquids used. However, if fluorocarbons are equilibrated with high gas partial pressures this effect should be investigated separately. Furthermore the effect of purity of the fluorocarbons, which were the available industrial grade, was not considered in this model study). The effect of temperature and the age of interface of the measured fluid systems (albumin, plasma and serum) against air and FC-43 is demonstrated in table 2. An increase of temperature of $20^{\circ} \mathrm{C}$ to $37^{\circ} \mathrm{C}$ causes a drop in the interfacial tension up to $20 \%$. The same tendency is evident for the fluid system measured against FC-43 (tab. IIb), however, the interfacial tension drop is generally more pronounced.

Table 2 also shows that the interfacial tension and surface tension of the studied fluids is not constant: there is a time dependence demonstrated which is a function of the age of the interface. This is expressed by the time drop in intervals of $5 \mathrm{~min}$. The results of studies with blood at different haematocrit values are given in table $3 a / b$. Here again the effect of temperature upon surface tension is demonstrated. A maximum value of $14 \%$ is obtained, which is less pronounced than surface teinsion of table 2. The interfacial tension shows a similar temperature effect to that of the surface tension data of table 2 . Table 3 shows a time dependence of the data similar to that obtained in table 2, but this experiment was performed with blood. The presence of surface active agents in biological fluids is the reason for the time drop characteristic of the systems. This phenomenon was described by Du Noüy in 1926(24). In figure 2 we tried to demonstrate this effect qualitatively on single samples of water, plasma, blood, (haematocrit $=0.45$ ) and amniotic fluid. The drop is given in percent of the first measurement after five minutes (five measurements in five minu-

Tab. 1. Surface and interfacial tension of water, isotonic saline and FC-43 against air and FC- 43 at $20^{\circ} \mathrm{C}$ and $37^{\circ} \mathrm{C}$ Mean values ( $n=30 \pm$ S.D.).

\begin{tabular}{lllll}
\hline & \multicolumn{2}{l}{$\begin{array}{l}\text { Phase 2: Air } \\
\overline{\mathrm{x}}=(\mathrm{m} \mathrm{N} / \mathrm{m})\end{array}$ S.D. } & \multicolumn{2}{l}{$\begin{array}{l}\text { Phase 2: FC-43 } \\
\overline{\mathrm{x}}=(\mathrm{mN} / \mathrm{m}) \pm \text { S.D. }\end{array}$} \\
\hline Phase 1 & $\mathrm{T}=20^{\circ} \mathrm{C}$ & $\mathrm{T}=37^{\circ} \mathrm{C}$ & $\mathrm{T}=20^{\circ} \mathrm{C}$ & $\mathrm{T}=37^{\circ} \mathrm{C}$ \\
Water & $72.6 \pm 0.1$ & $69.8 \pm 0.1$ & $50.7 \pm 0.1$ & $51.0 \pm 0.1$ \\
Saline & $72.1 \pm 0.1$ & $69.8 \pm 0.1$ & $53.0 \pm 0.1$ & $45.8 \pm 0.1$ \\
FC-43 & $16.1 \pm 0.1$ & $15.6 \pm 0.1$ & - & - \\
\hline
\end{tabular}

Tab. $2 a$ and $2 b$. Surface tension (a: against air) and interfacial tension (mean values \pm S.D.) (b: against fluorocarbon FC-43 (perfluorotributylamine)) of albumin, plasma and serum at $20^{\circ} \mathrm{C}$ and $37^{\circ} \mathrm{C}$ as a function of the interface age $(n=40)$.

\begin{tabular}{|c|c|c|c|c|c|c|}
\hline ab. $2 a$. & & & $\begin{array}{l}\text { Phase } 2 \\
\bar{x}=(\mathrm{m})\end{array}$ & $\begin{array}{l}: \text { Air } \\
N / m) \pm\end{array}$ & & \\
\hline $\begin{array}{l}\text { Age of } \\
\text { Interface } \\
\text { of Phase } 1 \\
\text { [min] }\end{array}$ & $\begin{array}{l}T=20 \\
\text { Albu- } \\
\text { min }\end{array}$ & $\begin{array}{l}{ }^{\circ} \mathrm{C} \\
\text { Plasma }\end{array}$ & Serum & $\begin{array}{l}\mathrm{T}=37 \\
\text { Albu- } \\
\mathrm{min}\end{array}$ & $\begin{array}{l}{ }^{\circ} \mathrm{C} \\
\text { Plasma }\end{array}$ & Serum \\
\hline 5 & $\begin{array}{r}53.0 \\
\pm 0.2\end{array}$ & $\begin{array}{r}49.1 \\
\pm 1.6\end{array}$ & $\begin{array}{r}46.0 \\
\pm 1.2\end{array}$ & $\begin{array}{r}47.7 \\
\pm 0.9\end{array}$ & $\begin{array}{r}41.1 \\
\pm 1.1\end{array}$ & $\begin{array}{r}41.1 \\
\pm 1.1\end{array}$ \\
\hline 10 & $\begin{array}{r}51.4 \\
\pm 0.2\end{array}$ & $\begin{array}{r}48.6 \\
\pm 1.4\end{array}$ & $\begin{array}{r}46.0 \\
\pm 1.0\end{array}$ & $\begin{array}{r}47.0 \\
\pm 0.2\end{array}$ & $\begin{array}{r}40.9 \\
\pm 1.1\end{array}$ & $\begin{array}{r}40.8 \\
\pm 1.3\end{array}$ \\
\hline 15 & $\begin{array}{r}50.0 \\
\pm 0.2\end{array}$ & $\begin{array}{r}48.4 \\
\pm 1.5\end{array}$ & $\begin{array}{r}45.8 \\
\pm 1.0\end{array}$ & $\begin{array}{r}46.9 \\
\pm 0.1\end{array}$ & $\begin{array}{r}40.7 \\
\pm 1.1\end{array}$ & $\begin{array}{r}40.7 \\
\pm 1.5\end{array}$ \\
\hline 20 & $\begin{array}{r}49.7 \\
\pm 0.1\end{array}$ & $\begin{array}{r}48.1 \\
\pm 1.3\end{array}$ & $\begin{array}{r}45.9 \\
\pm 1.0\end{array}$ & $\begin{array}{r}46.6 \\
\pm 0.1\end{array}$ & $\begin{array}{r}40.6 \\
\pm 1.1\end{array}$ & $\begin{array}{r}40.8 \\
\pm 1.4\end{array}$ \\
\hline 25 & $\begin{array}{r}49.7 \\
\pm 0.2\end{array}$ & $\begin{array}{r}48.0 \\
\pm 1.3\end{array}$ & $\begin{array}{r}45.8 \\
\pm 1.0\end{array}$ & $\begin{array}{r}46.4 \\
\pm 0.1\end{array}$ & $\begin{array}{r}40.5 \\
\pm 1.2\end{array}$ & $\begin{array}{r}40.6 \\
\pm 1.3\end{array}$ \\
\hline
\end{tabular}

\begin{tabular}{|c|c|c|c|c|c|c|}
\hline \multirow{2}{*}{$\begin{array}{l}\text { Tab. } 2 b . \\
\text { Age of } \\
\text { Interface } \\
\text { of Phase } 1 \\
\text { [min] }\end{array}$} & \multicolumn{6}{|c|}{$\begin{array}{l}\text { Phase 2: FC }=43 \\
\bar{x}=(\mathrm{mN} / \mathrm{m}) \pm S . D .\end{array}$} \\
\hline & $\begin{array}{l}\mathrm{T}=20 \\
\text { Albu- } \\
\mathrm{min}\end{array}$ & $\begin{array}{l}{ }^{\circ} \mathrm{C} \\
\text { Plasma }\end{array}$ & Serum & $\begin{array}{l}\mathrm{T}=37 \\
\text { Albu- } \\
\text { min }\end{array}$ & $\begin{array}{l}{ }^{\circ} \mathrm{C} \\
\text { Plasma }\end{array}$ & Serum \\
\hline 5 & $\begin{array}{r}30.9 \\
\pm 0.6\end{array}$ & $\begin{array}{r}30.2 \\
\pm 1,0\end{array}$ & $\begin{array}{r}27.8 \\
\pm 1.9\end{array}$ & $\begin{array}{r}28.1 \\
\pm 0.1\end{array}$ & $\begin{array}{r}22.8 \\
\pm 0.7\end{array}$ & $\begin{array}{r}22.6 \\
\pm 1.6\end{array}$ \\
\hline 10 & $\begin{array}{r}30.3 \\
\pm 0.5\end{array}$ & $\begin{array}{r}29.3 \\
\pm 0.7\end{array}$ & $\begin{array}{r}26.7 \\
\pm 1.9\end{array}$ & $\begin{array}{r}27.5 \\
\pm 0.1\end{array}$ & $\begin{array}{r}21.8 \\
\pm 0.4\end{array}$ & $\begin{array}{r}21.3 \\
\pm 1.3\end{array}$ \\
\hline 15 & $\begin{array}{r}29.8 \\
\pm 0.1\end{array}$ & $\begin{array}{r}29.0 \\
\pm 1.0\end{array}$ & $\begin{array}{r}26.2 \\
\pm 1.8\end{array}$ & $\begin{array}{r}27.0 \\
\pm 0.1\end{array}$ & $\begin{array}{r}21.4 \\
\pm 0.7\end{array}$ & $\begin{array}{r}20.8 \\
\pm 1.6\end{array}$ \\
\hline 20 & $\begin{array}{r}29.7 \\
\pm 0.1\end{array}$ & $\begin{array}{r}29.3 \\
\pm 2.6\end{array}$ & $\begin{array}{r}25.8 \\
\pm 1.6\end{array}$ & $\begin{array}{r}26.8 \\
\pm 0.1\end{array}$ & $\begin{array}{r}21.1 \\
\pm 1.0\end{array}$ & $\begin{array}{r}20.5 \\
\pm 1.7\end{array}$ \\
\hline 25 & $\begin{array}{r}29.7 \\
\pm 0.1\end{array}$ & $\begin{array}{r}29.2 \\
\pm 2.6\end{array}$ & $\begin{array}{r}25.4 \\
\pm 1.7\end{array}$ & $\begin{array}{r}26.7 \\
\pm 0.0\end{array}$ & $\begin{array}{r}21.0 \\
\pm 1.0\end{array}$ & $\begin{array}{r}20.3 \\
\pm 1.7\end{array}$ \\
\hline
\end{tabular}

tes intervals). Every biological fluid tested here (in contrast to water) possesses its own dynamic characteristic, depending on kind and concentration of surface active agents. At the beginning of the measurement the decrease of the surface tension is rapid, but after a time an asymptotic value is approached. Figure 2 shows that this fact is body fluid-specific, for example faster for plasma than for amniotic fluid. (In our experiments we could measure a significant time drop of surface tension for amniotic fluid even up to two hours).

Considering the blood (with its complex component composition) as one of the most typical biological fluids, the question arises, how can its surface tension best be studied? Our approach involves measuring the behaviour of the investigated components under the 
Tab. 3a and 3b. Surface tension (a: against air) and interface tension (mean values \pm S.D.) (b: against fluorocarbon FC-43 (perfluorotributylamine) of blood with different haematocrit values at $20^{\circ} \mathrm{C}$ and $37^{\circ} \mathrm{C}$ as a function of the interface age $(n=40)$.

Tab. 3a.

Phase 2: Air

\begin{tabular}{|c|c|c|c|c|c|c|}
\hline \multirow{2}{*}{$\begin{array}{l}\text { Age of } \\
\text { Interface } \\
\text { of Phase } 1 \\
\text { [min] }\end{array}$} & \multicolumn{6}{|c|}{$\overline{\mathrm{x}}=(\mathrm{mN} / \mathrm{m}) \pm$ S.D. } \\
\hline & $\begin{array}{c}\mathrm{T}=20 \\
\text { Haema- } \\
\text { tocrit } \\
0.45\end{array}$ & $\begin{array}{l}{ }^{\circ} \mathrm{C} \\
\text { Haema- } \\
\text { tocrit } \\
0.60\end{array}$ & $\begin{array}{l}\text { Haema- } \\
\text { to crit } \\
0.90\end{array}$ & $\begin{array}{c}\mathrm{T}=37 \\
- \text { Haema- } \\
\text { tocrit } \\
0.45\end{array}$ & $\begin{array}{l}{ }^{\circ} \mathrm{C} \\
\text { Haema- } \\
\text { tocrit } \\
0.60\end{array}$ & $\begin{array}{l}\text { Haema- } \\
\text { tocrit } \\
0.90\end{array}$ \\
\hline 5 & $\begin{array}{r}47.9 \\
\pm 1.9\end{array}$ & $\begin{array}{r}48.6 \\
\pm 2.4\end{array}$ & $\begin{array}{r}50.2 \\
\pm 1.6\end{array}$ & $\begin{array}{r}42.2 \\
\pm 1.4\end{array}$ & $\begin{array}{r}42.8 \\
\pm 1.3\end{array}$ & $\begin{array}{r}44.2 \\
\pm 2.3\end{array}$ \\
\hline 10 & $\begin{array}{r}47.7 \\
\pm 1.7\end{array}$ & $\begin{array}{r}47.6 \\
\pm 1.7\end{array}$ & $\begin{array}{r}49.3 \\
\pm 0.9\end{array}$ & $\begin{array}{r}41.6 \\
\pm 2.2\end{array}$ & $\begin{array}{r}42.0 \\
\pm 1.1\end{array}$ & $\begin{array}{r}43.2 \\
\pm 2.2\end{array}$ \\
\hline 15 & $\begin{array}{r}47.4 \\
\pm 1.2\end{array}$ & $\begin{array}{r}47.6 \\
\pm 2.0\end{array}$ & $\begin{array}{r}49.4 \\
\pm 1.9\end{array}$ & $\begin{array}{r}41.3 \\
\pm 1.8\end{array}$ & $\begin{array}{c}41.8^{\prime \prime} \\
\pm 1.1\end{array}$ & $\begin{array}{r}43.0 \\
\pm 2.0\end{array}$ \\
\hline 20 & $\begin{array}{r}47.2 \\
\pm 1.1\end{array}$ & $\begin{array}{r}47.0 \\
\pm 1.6\end{array}$ & $\begin{array}{r}48.5 \\
\pm 1.2\end{array}$ & $\begin{array}{r}41.3 \\
\pm 2.2\end{array}$ & $\begin{array}{r}41.3 \\
\pm 0.8\end{array}$ & $\begin{array}{r}42.9 \\
\pm 2.0\end{array}$ \\
\hline 25. & $\begin{array}{r}46.9 \\
\pm 0.9\end{array}$ & $\begin{array}{r}47.4 \\
\pm 1.9\end{array}$ & $\begin{array}{r}48.9 \\
\pm 1.9\end{array}$ & $\begin{array}{r}41.1 \\
\pm 1.9\end{array}$ & $\begin{array}{r}41.6 \\
\pm 1.2\end{array}$ & $\begin{array}{r}43.0 \\
\pm 1.8\end{array}$ \\
\hline
\end{tabular}

Tab. 3b.

Phase 2: FC-43

\begin{tabular}{|c|c|c|c|c|c|c|}
\hline \multirow[b]{2}{*}{$\begin{array}{l}\text { Age of } \\
\text { Interface } \\
\text { of Phase } 1 \\
\text { [min] }\end{array}$} & \multicolumn{6}{|c|}{$\overline{\mathrm{x}}=(\mathrm{mN} / \mathrm{m}) \pm \mathrm{S} . \mathrm{D}}$. \\
\hline & $\begin{array}{c}\mathrm{T}=20 \\
\text { Haema- } \\
\text { tocrit } \\
0.45\end{array}$ & $\begin{array}{l}{ }^{\circ} \mathrm{C} \\
- \text { Haema- } \\
\text { tocrit } \\
0.60\end{array}$ & $\begin{array}{l}\text { Haema- } \\
\text { tocrit } \\
0.90\end{array}$ & 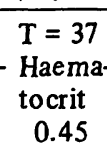 & $\begin{array}{l}{ }^{\circ} \mathrm{C} \\
- \text { Haema- } \\
\text { tocrit } \\
0.60\end{array}$ & $\begin{array}{l}\text { Haema- } \\
\text { to crit } \\
0.90\end{array}$ \\
\hline 5 & $\begin{array}{r}30.3 \\
\pm 1.9\end{array}$ & $\begin{array}{r}30.5 \\
\pm 1.6\end{array}$ & $\begin{array}{r}30.4 \\
\pm 2.1\end{array}$ & $\begin{array}{r}25.8 \\
\pm 2.2\end{array}$ & $\begin{array}{r}24.8 \\
\pm 1.3\end{array}$ & $\begin{array}{r}25.2 \\
\pm 1.4\end{array}$ \\
\hline 10 & $\begin{array}{r}29.2 \\
\pm 2.1\end{array}$ & $\begin{array}{r}29.4 \\
\pm 1.7\end{array}$ & $\begin{array}{r}29.4 \\
\pm 2.0\end{array}$ & $\begin{array}{r}25.2 \\
\pm 2.8\end{array}$ & $\begin{array}{r}24.2 \\
\pm 1.5\end{array}$ & $\begin{array}{r}24.9 \\
\pm 1.1\end{array}$ \\
\hline 15 & $\begin{array}{r}29.0 \\
\pm 2.1\end{array}$ & $\begin{array}{r}29.0 \\
\pm 1.9\end{array}$ & $\begin{array}{r}29.3 \\
\pm 2.3\end{array}$ & $\begin{array}{r}24.4 \\
\pm 2.5\end{array}$ & $\begin{array}{r}23.8 \\
\pm 1.2\end{array}$ & $\begin{array}{r}24.3 \\
\pm 1.4\end{array}$ \\
\hline 20 & $\begin{array}{r}28.5 \\
\pm 2.3\end{array}$ & $\begin{array}{r}28.1 \\
\pm 1.7\end{array}$ & $\begin{array}{r}28.3 \\
\pm 2.0\end{array}$ & $\begin{array}{r}24.1 \\
\pm 3.0\end{array}$ & $\begin{array}{r}23.6 \\
\pm 1.6\end{array}$ & $\begin{array}{r}24.5 \\
\pm 1.3\end{array}$ \\
\hline 25 & $\begin{array}{r}28.8 \\
\pm 2.2\end{array}$ & $\begin{array}{r}28.5 \\
\pm 1.7\end{array}$ & $\begin{array}{r}28.9 \\
\pm 2.2\end{array}$ & $\begin{array}{r}23.0 \\
\pm 1.1\end{array}$ & $\begin{array}{r}23.0 \\
\pm 1.1\end{array}$ & $\begin{array}{r}24.1 \\
\pm 1.4\end{array}$ \\
\hline
\end{tabular}

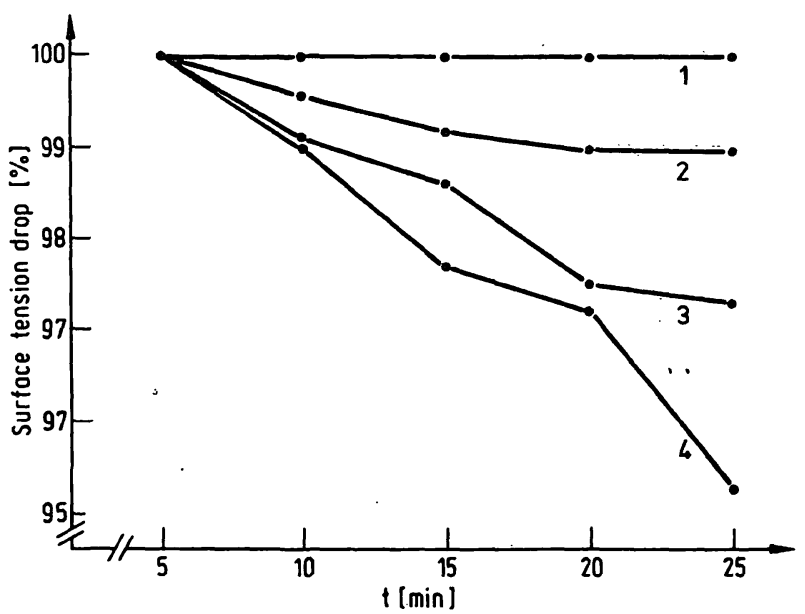

Fig. 2. Effect of the interface age upon surface tension drop (derived by measuring at 5 minute intervals) in percent of first measurement. $1=$ water; $2=$ plasma; $3=$ blood (haemato crit $=0.45$ ); $4=$ amniotic fluid at $20^{\circ} \mathrm{C}$. same conditions. The effect of erythrocytes was investigated by increasing the haematocrit (tab. 3), which does not influence the value of interfacial tension and surface tension significantly. Preliminary experiments using the ring-method, showed no significant influence of the platelet number on the surface tension. As shown in table 2, plasma, serum and albumin were measured, in particular to study the effect of the proteins. Principally, the same tendency is valid for interfacial tension measurements against fluorocarbon. It was mentioned earlier that measurements of interfacial tension against inert liquids (here fluorocarbons) instead of air could have some advantages: The "reference" fluid (fluorocarbon) provides more stability than air because of its incompressibility, and it has a good heat condictivity. A further application worth noting is that where there are problems of absorption (e.g. blood (1)) to solid surfaces, the reference fluid could act as a model with the interfacial tension as a helpful parameter (for example Teflon ${ }^{\circledR}$ and fluorocarbons are related materials). This requires, however, more precise techniques. Finally, the interfacial tension itself is necessary, if gas transport studies are intended (18). To conclude the discussion, a number of surface tension measurements of some body fluids obtained by different groups is listed in table 4.

Tab. 4. Surface tension of some biological fluids obtained by different groups (for more details see the sources).

\begin{tabular}{|c|c|c|c|c|}
\hline $\begin{array}{l}\sigma \\
{[\mathrm{mN} / \mathrm{m}]}\end{array}$ & $\begin{array}{l}\text { Body } \\
\text { Fluid }\end{array}$ & Method & $\begin{array}{l}\text { Temp. } \\
{\left[0^{\circ} \mathrm{C}\right]}\end{array}$ & $\begin{array}{l}\text { Refer- } \\
\text { ence }\end{array}$ \\
\hline 48 & Bile & $\begin{array}{l}\text { Tensiometer } \\
\text { (Dognon \& Abribat) }\end{array}$ & 20 & (9) \\
\hline 42 & Bile & Drop Volume Method & 37 & $(10)$ \\
\hline $55.5-61.2$ & Blood & - & 20 & (11) \\
\hline $\begin{array}{l}63.6 \\
\text { (dynamic) } \\
61.0 \\
\text { (static) }\end{array}$ & $\begin{array}{l}\text { Cerebro- } \\
\text { spinal } \\
\text { Fluid }\end{array}$ & $\begin{array}{l}\text { Tensiometer } \\
\text { (Du Noüy) }\end{array}$ & 20 & (7) \\
\hline $\begin{array}{l}59.2 \\
\text { (dynamic) } \\
56.2 \\
\text { (static) }\end{array}$ & Serum & $\begin{array}{l}\text { Tensiometer } \\
\text { (D̈u Noüy) }\end{array}$ & - & $(8)$ \\
\hline 65 & Lymph & $\begin{array}{l}\text { Tensiometer } \\
\text { (Dognon \& Abribat) }\end{array}$ & 20 & (9) \\
\hline $45.5-57.4$ & Saliva & $\begin{array}{l}\text { Tensiometer } \\
(D u \text { Nö̈y })\end{array}$ & - & $(12)$ \\
\hline 65 & Serum & $\begin{array}{l}\text { Tensiometer } \\
\text { (Dognon \& Abribat) }\end{array}$ & 20 & (9) \\
\hline 66 & Sperm & $\begin{array}{l}\text { Stalagmometer } \\
\text { (Traube) }\end{array}$ & 20 & (13) \\
\hline $52-59.5$ & Sperm & - & 15 & (14) \\
\hline $69-70$ & Sweat & Capillary Rise Method & $37-38$ & (15) \\
\hline $36.9-43$ & Tears & $\begin{array}{l}\text { Contact Angle } \\
\text { Goniometry. }\end{array}$ & - & $(16)$ \\
\hline 66 & Urine & $\begin{array}{l}\text { Tensiometer } \\
\text { (Dognon \& Abribat) }\end{array}$ & 20 & $\begin{array}{r}(9)^{\cdots}: \\
\quad \ldots\end{array}$ \\
\hline $64-69$ & Urine & - & $\cdots$ & (17) \\
\hline
\end{tabular}


If the changes in surface tension values have a diagnostic significance, the measurement conditions and methods should be standardized. The knowledge of time dependence of the surface tension for any biological fluid is necessary; this is a dynamic measurement in contrast to a static one. The lack of the above conditions is the reason for discrepancies found in the literature (see tab. $2,3,4)$, thus a comparison is difficult if not impossible.

Therefore it is reasonable to suggest standardization. We propose the following conditions which should be fulfilled:

- age of the biological fluid should be defined

- age of the interface of the systems should be defined

- measurements performed at constant temperature

- preparation of the biological fluids should be standardized; this is, for instance, in the case of amnio- tic fluid, very important, and includes the mode of centrifugation, elimination of the contaminats and effects of freezing samples

- the type of anticoagulant which is significant in the case of blood and should be standardized

- the use of different devices renders more difficult the comparison of the measurement on the same liquid system. Therefore correction factors should be taken into consideration

- to avoid subjective errors, e.g. in the case of $D u$ Noüy apparatus, the detaching of the ring should be automatized (e.g. motor driven)

\section{Acknowledgements}

The authors wish to thank Professor Dr. med. B. Deuticke for the helpful discussions and Miss I. Dringenberg for her excellent technical assistance.

\section{References}

1. Galletti, P. M. (1971), Fed. Proc. 30, 1491-1493.

2. Peirce, E. C. (1969), Extracorporal Circulation for OpenHeart Surgery. Charles C. Thomas Publisher, Springfield/ Illinois.

3. Zapol, W. M., Levy, R. I., Kolobow, T., Spragg, R. \& Bowman, R. L. (1969), Top. Surg. Res. 1, 449-467.

4. Kolff, W. J. (1976), Artificial Organs. Wiley, New York, Toronto.

5. Masson, D., Diedrich, K., Rehm, G., Stefan, M. \& SchultzeMosgau, H. (1977), Geburtshilfe Frauenheilk. 37, 57-63.

6. Mottaghy, K., Hahn, A., Schwenzel, W. \& Kopecky, P. (1979), Biomed. Technik 24, 349-350.

7. Künzel, O. (1936), Dtsch. Z. Nervenheilk. 139, 265-277.

8. Künzel, O. (1941), Ergebn. Inn. Med. Kinderheilkd. 60, $565-656$.

9. Loiseleur, J. (1947), Technique de Laboratoire, Masson et Cie Editeurs, Libraires de l'Académie de Médicine, Chapitre V, Paris pp. 52-54.

10. De Palma, R. G., Hubay, C. A. \& Levey, S. (1966), The J. Am. Med. Ass. 195, 159-161.

11. Dittmer, D. S. (ed.) (1961). Blood and Other Body Fluids. Fed. of American Soc. for Exp. Biology, Washington, D.C, p. 12.

12. Alfonsky, D. (1961), Saliva and its Relation to Oral Health. University of Alabama Press., p. 32.

13. Zagami, V. (1939), Arch. Sci. Biol. (Bologna) 25, 208-253.

14. Documenta Geigy (1968), Wissenschaftliche Tabellen, S. 678.

15. Randall, W. C. \& Calman, C. (1954), J. Invest. Dermatol 23, 113-118.
16. Holly, F. J., Patten, J. T. \& Dohlman, C. H. (1977), Exp. Eye Res. 24, 479-491.

17. Flaschenträger, B. \& Lehnartz, E. (eds.) (1957), Physiologische Chemie II/2b. Springer Verlag, Berlin-GöttingenHeidelberg, p. 81.

18. Mottaghy, K., Driessen, G., Zander, M., Kreisel, C., Mendler, N. \& Schmid-Schönbein, H. (1977), Trans. Am. Soc. Artif. Intern. Organs, 23, 464-468.

19. Teitel, P. (1977), Blood Cells, 3, 55-70.

20. Clark, L. C. (1970), Fed. Proc. 29, 1695-1820.

21. Geyer, R. P. (Chairman) (1975), Blood Fed. Proc., 34, $1428-1531$.

22. Davies, J. T. \& Rideal, E. K. (1963), Interfacial Phenomena. Acad. Press., New York and London.

23. Prandtl, L. (1947), Annalen der Physik. 6. Folge, Bd. 1, S. 59.

24. Du Noüy, P. (1926), Surface Equilibris of Colloids. American Chem. Soc., Monograph Series. J. J. Little and Ives Company, New York

25. Finzel, R. \& Seemann, F. W. (1977), PTB-Mitteilungen, 87, 296-301.

26. Harkins, W. D. \& Jordan, H. F. (1930), J. Am. Chem. Soc., $52,1751-1772$

27. Fox, H. W. \& Chrisman, C. H. (1952), J. Phys. Chem., 56, 284-287.

28. Zuidema, H. \& Waters, C. W. (1941), Ind. Eng. Chem. Analyt. 13, 312-313.
Dr. K. Mottaghy Abteilung Physiologie der RWTH Aachen Schneebergweg 211 D-5100 Aachen 
